\title{
Screening, Cloning, Expression and Characterization of New Alkaline Trehalose Synthase from Pseudomonas monteilii and Its Application for Trehalose Production
}

\author{
Srisakul Trakarnpaiboon ${ }^{1}$, Benjarat Bunterngsook ${ }^{1}$, Rungtiva Wansuksriand ${ }^{2}$, and \\ Verawat Champreda ${ }^{1 *}$
}

${ }^{1}$ Enzyme Technology Research Team, Biorefinery and Bioproduct Technology Research Group, National Center for Genetic Engineering and Biotechnology, 113 Thailand Science Park, Paholyothin RD., Klong Luang District, Pathumthani 12120, Thailand

${ }^{2}$ Cassava and Starch Technology Research Team, Functional Ingredients and Food Innovation Research Group, National Center for Genetic Engineering and Biotechnology, Bangkok 10900, Thailand

\begin{abstract}
Trehalose is a non-reducing disaccharide in increasing demand for applications in food, nutraceutical, and pharmaceutical industries. Single-step trehalose production by trehalose synthase (TreS) using maltose as a starting material is a promising alternative process for industrial application due to its simplicity and cost advantage. Pseudomonas monteilii TBRC 1196 was identified using the developed screening method as a potent strain for TreS production. The TreS gene from $P$. monteilii TBRC 1196 was first cloned and expressed in Escherichia coli. Purified recombinant trehalose synthase (PmTreS) had a molecular weight of $76 \mathrm{kDa}$ and showed optimal pH and temperature at 9.0 and $40^{\circ} \mathrm{C}$, respectively. The enzyme exhibited $>90 \%$ residual activity under mesophilic condition under a broad pH range of 7-10 for $6 \mathrm{~h}$. Maximum trehalose yield by PmTreS was $68.1 \%$ with low yield of glucose $(4 \%)$ as a byproduct under optimal conditions, equivalent to productivity of $4.5 \mathrm{~g} / \mathrm{l} / \mathrm{h}$ using enzyme loading of $2 \mathrm{mg} / \mathrm{g}$ substrate and high concentration maltose solution (100 g/l) in a lab-scale bioreactor. The enzyme represents a potent biocatalyst for energysaving trehalose production with potential for inhibiting microbial contamination by alkaline condition.
\end{abstract}

Keywords: Trehalose, trehalose synthase, maltose, Pseudomonas monteilii

Received: June 11, 2021 Accepted: August 19, 2021

First published online: August 21, 2021

*Corresponding author Phone: $+6625646700 \times 3446$ Fax: +6625646707 E-mail: verawat@biotec.or.th

Supplementary data for this paper are available on-line only at http://jmb.or.kr.

pISSN 1017-7825 elSSN 1738-8872

Copyright $\odot 2021$ by the authors. Licensee KMB. This article is an open access article distributed under the terms and conditions of the Creative Commons Attribution (CC BY) license.

\section{Introduction}

Trehalose or $\alpha$-D-glucopyranosyl- $\alpha$-D-glucopyranoside is a non-reducing disaccharide certified by the US Food and Drug Administration as a Generally Recognized as Safe (GRAS) ingredient in 2000 [1]. It has various applications in the food, cosmetic and pharmaceutical industries as a preservative, stabilizer or moisturizer for frozen foods, vaccines and skincare products [2-4]. Trehalose can be produced by chemical and biosynthesis. Chemical synthesis utilizes the reaction of 2,3,4,5-tetra-O-acetyl-D-glucose with 3,4,6-tri-O-acetyl-1,2-anhydro$\mathrm{D}$-glucose in benzene but with a low yield and at high cost $[1,5]$. In the biological route, trehalose is produced as a source of energy, and functions in cell protection under stress condition in living organisms [6-8].

Currently, five different biosynthesis pathways have been reported for trehalose production in microbes as (1) trehalose-6-phosphate synthase and trehalose-phosphatase (TPP), (2) maltooligosyltrehalose synthase and maltooligosyltrehalose trehalohydrolase (MTHase/MTHase), (3) trehalose synthase (TreS), (4) trehalose phosphorylase (TreP), and (5) trehalose glycosyltransferring synthase (TreT) [1,2]. The major disadvantage in the application of the three pathways (TPP, TreP, and TretT) is mainly in the need to use glucose and derivatives of glucose (glucose-6-phosphate, ADP-glucose or glucose-1- phosphate) as the starting materials [2, 9]. This makes up-scaling of the processes for industrial application economically infeasible due to the cost of preparing the glucose derivatives. The MTHase/MTHase gave high trehalose yield and has been implemented for commercial production of trehalose from starch [10-13]; however, generation of mixed byproducts (branched starch, maltose and maltotriose) and the long reaction time needed for the two-step enzymatic reaction are disadvantageous [13]. Hence, an alternative trehalose production process by TreS has attracted research interest.

A one-step trehalose production from maltose can be catalyzed by TreS. TreS enzymes are found in several bacteria and archaea such as Thermus aquaticus, Mycobacterium smegmatis, Picrophilus torridus, Deinococcus 
geothermalis, Corynebacterium glutamicum and Pseudomonas stutzeri [14-19]. This enzyme catalyzes an intramolecular rearrangement of the $\alpha$-1,4-glycosidic bond of maltose to the $\alpha, \alpha,-1,1$-linkage of trehalose in the absence of coenzyme [20], making it a potential biocatalyst for simple conversion of maltose to trehalose. TreS enzymes have been characterized from many microorganisms but most have low stability under operational conditions and generate high glucose as a byproduct [13].

Production of maltose syrup from cassava is a well-established industry in Thailand. Valorization of the lowpriced maltose to secondary products of higher commercial value is of great interest for the industry. Our aim in this study is to discover a new TreS enzyme with properties desirable for industrial application, i.e., high stability under operating conditions with low generation of glucose as a byproduct. A protocol for screening TreSproducing strains was developed with the use of effective induction media. The TreS gene from a potential strain was cloned and expressed and the recombinant TreS was characterized for its biochemical properties. The alkaliphilic property of the enzyme is considered advantageous as it inhibits contaminated microbes while enabling operation under energy saving mesophilic conditions. Conversion of maltose to trehalose using this enzyme was investigated in a bioreactor, showing its potential for future biotechnological application.

\section{Materials and Methods}

Bacterial Strains, Plasmids and Culture Conditions

Microorganisms for screening and selection for TreS production were obtained from the Thailand Bioresource Research Center (TBRC) (www.tbrcnetwork.org) and the Thailand Institute of Scientific and Technological Research (TISTR) (https://www.tistr.or.th/tistr_culture). P. monteilii TBRC 1196 from the Thailand Biological Resource Center was used as a source of the TreS gene. The bacteria were cultivated in nutrient broth medium on a rotary shaker at $30^{\circ} \mathrm{C}$. E. coli DH5 $\alpha$ and BL21 (DE3) (Novagen, USA) were used as a cloning host and expression host, and cells with plasmids were cultured at $37^{\circ} \mathrm{C}$ in Luria-Bertani broth supplemented with ampicillin $(34 \mu \mathrm{g} /$ $\mathrm{ml})$ and kanamycin $(50 \mu \mathrm{g} / \mathrm{ml})$, respectively.

\section{Method for Screening of TreS-Producing Strains}

The bacteria were cultivated in three screening media. The first was the growth medium recommended for each strain by TBRC and TISTR (nutrient broth, marine agar, MRS broth, or ISP2 broth). The second was the osmotic medium prepared by addition of $1 \%(\mathrm{w} / \mathrm{v}) \mathrm{NaCl}$ to the growth media [21], and the third was maltose medium consisting of $10 \%(\mathrm{w} / \mathrm{v})$ maltose, $5 \%(\mathrm{w} / \mathrm{v})$ peptone, $1 \%(\mathrm{w} / \mathrm{v})$ yeast extract, $1 \%(\mathrm{w} / \mathrm{v}) \mathrm{K}_{2} \mathrm{HPO}_{4}, 1 \%(\mathrm{w} / \mathrm{v}) \mathrm{NaH}_{2} \mathrm{PO}_{4}$, $0.5 \%(\mathrm{w} / \mathrm{v}) \mathrm{MgSO}_{4} \cdot 7 \mathrm{H}_{2} \mathrm{O}$ and $0.1 \%(\mathrm{w} / \mathrm{v}) \mathrm{CaCl}_{2}$ as modified from $\mathrm{Zhu}$ et al. with an addition of maltose [22]. All target strains were grown in $5 \mathrm{ml}$ cultures at $30^{\circ} \mathrm{C}$ with agitation at $200 \mathrm{rpm}$ for 24 and $48 \mathrm{~h}$. The cells were pelleted by centrifugation at $6,000 \times g$ for $10 \mathrm{~min}$ at $4^{\circ} \mathrm{C}$ and kept at $-20^{\circ} \mathrm{C}$ overnight. Then, the cells were resuspended in $1 \mathrm{ml}$ of $50 \mathrm{mM}$ potassium phosphate buffer ( $\mathrm{pH}$ 7.0). The cells were lysed using an Ultrasonic Processor VCX 130 PB (Sonics \& Materials, Inc., USA) with a $3 \mathrm{~mm}$ diameter probe at a frequency of $20 \mathrm{kHz}$ and $80 \%$ of amplitude for 30 and $60 \mathrm{sec}$. Crude cell extracts were analyzed for protein content and TreS activity.

The TreS activity was assayed based on trehalose released from maltose according to the method modified from Cai et al. [23]. To validate the rapid trehalose assay protocol for screening, trehalose standard solution $(2,4,10,20$, 60, and $100 \mathrm{~g} / \mathrm{l}$ ) was analyzed by a Trehalose Assay Kit (Megazyme International, Ireland) and high-performance liquid chromatography (SPD-M10A DAD, Shimadzu, Japan) equipped with a refractive index detector and a Shodex HILICpak VG-50 4E column $(4.6 \times 250 \mathrm{~mm}, 5 \mu \mathrm{m})$ at $1.0 \mathrm{ml} / \mathrm{min}$. Column oven temperature was set at $40^{\circ} \mathrm{C}$ and the mobile phase consisted of a mixture of $80 \%$ acetonitrile and $20 \%$ ultrapure water.

For TreS activity assay, $0.5 \mathrm{ml}$ of the crude cell extracts was mixed with $0.5 \mathrm{ml}$ of $5 \%(\mathrm{w} / \mathrm{v})$ maltose solution in $50 \mathrm{mM}$ potassium phosphate buffer $\left(\mathrm{pH}\right.$ 7.0). The reaction mixture was incubated at $40^{\circ} \mathrm{C}$ for $3 \mathrm{~h}$. The reaction was stopped by heating at $95^{\circ} \mathrm{C}$ for $15 \mathrm{~min}$, and the mixture was centrifuged at $4^{\circ} \mathrm{C}$ and $8,000 \mathrm{rpm}$ for $5 \mathrm{~min}$. The amount of trehalose in the reaction mixture was measured by a Trehalose Assay Kit (Megazyme). One TreS unit is the amount of enzyme required to produce $1 \mu \mathrm{mol} / \mathrm{min}$ of trehalose from maltose.

\section{Cloning and Expression of TreS Gene}

The DNA of P. monteilii TBRC 1196 was prepared using a bacterial genome DNA extraction kit (Thermo Scientific, Inc., USA). The putative gene encoding TreS was amplified by a polymerase chain reaction (PCR) using PmTreS forward (5'-GCCCATGGCGATGACCCAACCCGACCCGTCATAC-3') and reverse (5'-CTCGAG GACATGCCCACTGCTGTTGACGAT-3') primers designed based on the TreS gene from P. monteilii SB3101. The recognition sites for NcoI and XhoI are underlined and the start and stop codons are in bold letters [24]. The PCR reactions contained DNA template, $10 \mathrm{mM}$ dNTPs, $10 \mu \mathrm{M}$ primers, DNA polymerase, $10 \mathrm{x}$ GC buffer and nanopure water. The target gene was amplified using the following conditions: pre-denaturation $\left(98^{\circ} \mathrm{C}, 30 \mathrm{sec}\right), 30$ cycles of denaturation $\left(98^{\circ} \mathrm{C}, 10 \mathrm{sec}\right)$, annealing $\left(64^{\circ} \mathrm{C}, 30 \mathrm{sec}\right)$, extension $\left(72^{\circ} \mathrm{C}, 2 \mathrm{~min}\right)$ and prolonged elongation $\left(72^{\circ} \mathrm{C}, 10 \mathrm{~min}\right)$. The PmTreS gene from the PCR reaction was purified using a GeneJET Gel Extraction Kit (Thermo Scientific, Inc.), then cloned into a pJET1.2 vector (Fermentas UAB, Lithuania) and transformed into $E$. coli $\mathrm{DH} 5 \mathrm{a}$ for sequencing. The purified pJET1.2 vector containing the PmTreS gene fragment was digested with $\mathrm{NcoI}$ and $\mathrm{XhoI}$, ligated into pET-28a(+) (Novagen) digested with the same restriction enzymes and transformed into E. coli BL21(DE3) for enzyme expression.

Sequence analysis of PmTreS was performed on the BLAST server of the National Center for Biotechnology Information (https://blast.ncbi.nlm.nih.gov/Blast.cgi). Multiple amino acid sequence alignment was performed using the online program Clustal Omega (https://www.ebi.ac.uk/Tools/msa/clustalo/). 
The E. coli BL21 (DE3) cells harboring the pET28a-PmTreS plasmid were cultured in Luria-Bertani broth supplemented with $50 \mu \mathrm{g} / \mathrm{ml}$ of kanamycin and incubated at $37^{\circ} \mathrm{C}$. When the optical density of the culture reached 0.6 , IPTG was added to a final concentration of $1 \mathrm{mM}$. Then, PmTreS was further cultivated at 37,25 , and $18^{\circ} \mathrm{C}$ for 3,6 , and $20 \mathrm{~h}$, respectively.

\section{Purification of Recombinant TreS}

The culture broth was centrifuged at $6,000 \times g$ for $10 \mathrm{~min}$ and the pellet was re-suspended in $10 \mathrm{mM}$ potassium phosphate buffer ( $\mathrm{pH} 7.0$ ). The cells were disrupted by sonication as described above. The cell extract was clarified by centrifugation at $6,000 \times g$ for $30 \mathrm{~min}$ and applied to a His trap FF column (GE Healthcare, UK), preequilibrated with the same buffer. Unbound proteins were removed by washing with the same buffer. Bound proteins were eluted with the elution buffer $(20 \mathrm{mM}$ potassium phosphate buffer, $\mathrm{pH} 7.4$, and $500 \mathrm{mM} \mathrm{NaCl}$, and $60 \mathrm{mM}$ imidazole). Protein concentration was determined using a Bio-Rad Protein Assay Kit (BioRad Laboratory, USA). The protein profiles in collected fractions were analyzed by sodium dodecyl sulfate polyacrylamide gel electrophoresis (SDS-PAGE).

\section{Biochemical Characterization of TreS}

The effect of temperature on TreS activity was measured at $20-70^{\circ} \mathrm{C}$ in $50 \mathrm{mM}$ potassium phosphate buffer $(\mathrm{pH}$ 7.0). For optimal $\mathrm{pH}$ determination, enzyme activity at various $\mathrm{pH}$ values was examined at $40^{\circ} \mathrm{C}$ in a buffer containing $1 \%$ maltose. The following buffers were used: $50 \mathrm{mM}$ sodium acetate ( $\mathrm{pH} 3.0-5.0), 50 \mathrm{mM}$ potassium phosphate (pH 6.0-8.0), and $50 \mathrm{mM}$ glycine- $\mathrm{NaOH}$ ( $\mathrm{pH}$ 9.0-11.0).

Thermal stability was determined by measuring residual enzyme activity after pre-incubation of the enzyme without the substrate at 20 to $70^{\circ} \mathrm{C}$ for $1,2,4,6,12$, and $24 \mathrm{~h}$. To determine the effect of $\mathrm{pH}$ on stability, the recombinant enzyme was first incubated in buffers with different $\mathrm{pH}$ values ranging from 3.0 to 7.0 . After incubation at $30^{\circ} \mathrm{C}$ for $24 \mathrm{~h}$, the residual enzyme activity was measured at $40^{\circ} \mathrm{C}$ and $\mathrm{pH} 7.0$ using the method described above.

The effects of metal ions $\left(\mathrm{Zn}^{2+}, \mathrm{Mg}^{2+}, \mathrm{Ca}^{2+}, \mathrm{Cu}^{2+}, \mathrm{Ba}^{2+}, \mathrm{Ni}^{2+}\right.$, and $\left.\mathrm{Fe}^{2+}\right)$ on enzyme activity were assayed at a concentration of $1 \mathrm{mM}$. All metals were used in chloride form. The enzyme was pre-incubated with $3 \mathrm{mM}$ EDTA in $50 \mathrm{mM}$ potassium phosphate buffer, $\mathrm{pH} 7.0$, for $30 \mathrm{~min}$ at $30^{\circ} \mathrm{C}$. The excess EDTA was removed by buffer exchange using centrifugation tubes (Mw cut-off $10 \mathrm{kDa}$ ). The amount of trehalose was determined by HPLC as described above. Relative activity without any metal ions was defined as $100 \%$.

To determine the effects of substrate concentration on enzyme activity, the purified enzyme was mixed with $50 \mathrm{mM}$ glycine- $\mathrm{NaOH}$ buffer ( $\mathrm{pH}$ 9.0) containing various maltose concentrations of $10,50,100,150,200$, and $250 \mathrm{~g} / \mathrm{l}$ and incubated at $40^{\circ} \mathrm{C}$ for $24 \mathrm{~h}$.

\section{Trehalose Production from Maltose in Bioreactor}

Production of trehalose was preliminarily studied using purified PmTreS ( $2 \mathrm{mg} / \mathrm{g}$ of substrate) in a reaction containing $50 \mathrm{ml}$ of $100 \mathrm{~g} / \mathrm{l}$ maltose in $50 \mathrm{mM}$ potassium phosphate buffer $\mathrm{pH} 7.0,8.0$ and $50 \mathrm{mM}$ glycine- $\mathrm{NaOH}$ $\mathrm{pH}$ 9.0, and incubated at 30 and $40^{\circ} \mathrm{C}$ for $24 \mathrm{~h}$. Up-scaled trehalose production by TreS was carried out in a 2-L stirred tank bioreactor (MDET-N-2L, B.E. Thailand) using $1 \mathrm{~L}$ of maltose $(100$ and $200 \mathrm{~g} / \mathrm{l})$ as a substrate, at $40^{\circ} \mathrm{C}$ and $\mathrm{pH} 9.0$ with mixing at $50 \mathrm{rpm}$ under the same condition as described above. Samples were taken at different time intervals and heated at $100^{\circ} \mathrm{C}$ for $10 \mathrm{~min}$ to stop the reaction. The trehalose produced was measured by HPLC.

\section{Analysis}

Sugar assay was performed following the method of Kuschel et al. [25] with minor modifications. Concentrations $(\%, \mathrm{w} / \mathrm{v})$ of glucose, maltose and trehalose were analyzed on a high-performance liquid chromatograph (LC20ASeries, Shimadzu-GL Sciences, Japan) equipped with a Shodex HILICpak VG-50 4E column $(4.6 \times 250 \mathrm{~mm}, 5$ $\mu \mathrm{m})$ column at $40^{\circ} \mathrm{C}$. Acetonitrile:ultrapure water $(80: 20 \mathrm{v} / \mathrm{v})$ was used as the mobile phase at a flow rate of $1.0 \mathrm{ml} /$ min.

The total amount of protein in crude cell extracts was analyzed by the Bradford method using a Bio-Rad Protein Assay Kit (BioRad Laboratory) with bovine serum albumin (BSA) as a standard.

\section{Statistical Methods}

The data obtained were subjected to one-way analysis of variance using SPSS statistical software, release 11.5 (SPSS Inc., USA). Duncan's multiple range test was performed to determine significant differences of the means, with significance level set at $p \leq 0.05$.

\section{Results and Discussion}

\section{Development of Protocol for TreS-Producing Strain Screening}

The traditional method for screening TreS required a large volume of culture and preparation of crude cell extract and trehalose detection was time consuming [26, 27]. In this study, a modified screening method was developed by selection of screening media for small-scale cultivation, optimization of the crude extract preparation method and validation of enzyme activity assay on a small scale. First, the three screening media, including the optimal growth medium, optimal growth medium plus $\mathrm{NaCl}$ (salt stress condition) and maltose medium (sugar stress condition) were investigated to select the potential medium for screening on a small scale 
( $5 \mathrm{ml}$ in screw-cap culture tubes). Twenty-one strains from 14 genera previously reported for TreS production were investigated as the candidate strains in this experiment. The results showed that the maltose medium was the most potent for screening of TreS-producing strains because 19 of 21 strains showed TreS activity when cultured in this medium for 24-48 h, whereas trehalose synthase activity from some strains could not be found in the other two media (Fig. S1A). Microorganisms produced an intracellular trehalose content to enable the cells to resist physicochemical stresses [28]. Addition of sugars and inorganic salts in the medium can create stress conditions leading to increased trehalose production. An increase in intracellular trehalose was reported to promote growth of the microbes under osmotic stress [21,29]. Results showing different levels of TreS activity obtained from different media for the same strain might be due to diverse types of stresses and induction effects that resulted in variation in trehalose formation by each strain. However, some strains did not show TreS activity in all screening media, suggesting their inability to produce enzyme.

Subsequently, two methods including freeze-thawing at $-20^{\circ} \mathrm{C}$ and sonication at 30 and $60 \mathrm{sec}$ were investigated to reduce cell extraction time. The results revealed that protein contents in cell extraction obtained at 30 and $60 \mathrm{sec}$ of sonication were similar (Fig. S1B), whereas the freeze-thaw method resulted in less protein content than the sonication method. Therefore, sonication at $30 \mathrm{sec}$ was chosen for the rapid screening protocol.

To set up the high-throughput method for trehalose analysis in the screening protocol, the trehalose assay kit was applied and compared with the HPLC method. Data on trehalose concentration from these two methods were plotted to see their correlation. The results showed that the two methods correlated with good agreement in the range of $0-100 \mathrm{~g} / \mathrm{l}$ of trehalose, suggesting that the trehalose assay kit could be used to estimate TreS in the screening process (Fig. S1C). The developed method is advantageous in terms of time, throughput, and reaction scale compared to previously reported methods, using the screening protocols based on TLC or HPLC [26, 27] (Fig. S2)

The developed screening method was then applied for the screening experiment. Target microorganisms for screening were chosen from genera previously reported for TreS or maltose $\alpha$-D-glucosyltransferase gene by TBRC and TISTR. Of 169 strains screened, 60 strains showed TreS activity (Fig. S3). Among these, P. monteilii TBRC 1196 was selected as it showed the highest ability to convert maltose into trehalose compared to the other strains. The enzyme from this identified bacterial strain was selected for further characterization.

\section{Identification, Cloning and Sequencing of TreS Gene from $P$. monteilii}

The TreS gene from P. monteilii TBRC 1196 with a length of 2,091 bp was successfully amplified (see Fig. S4). The gene encoded a polypeptide containing 697 amino acid residues with a predicted molecular mass of $76.7 \mathrm{kDa}$. Amino acid sequence comparison of mesophilic TreS indicated that PmTreS showed the highest identity of $96 \%$ to $\mathrm{PmTreS}_{\mathrm{SB} 3101}$ : P. monteilii [GenBank: AHC88446.1] and 95\% identity with PmTreS $\mathrm{SB}_{\mathrm{S} 3078}:$ P. monteilii [GenBank: AHC83070.1] and TreS from P. putida [GenBank: QNG09137.1], 71\% identity with that of P. stutzeri [GenBank: AAF26837] and 20-30\% identity with PpTreS: P. putida [GenBank: TFF50727.1], AcTreS: Arthrobacter chlorophenolicus [GenBank: AKA87409.1], AaTreS: A. aurescens [GenBank: ACL80570.1], DrTreS: D. radiodurans [GenBank: AEJ36289], RoTreS: Rhodococcus opacus [GenBank: AGF84773.1], EhTreS: Enterobacter hormaechei [GenBank: ACI16355.1] and CgTreS: C. glutamicum [GenBank: CAF20645]. It should be noted that the TreS enzymes from P. monteilii SB3101 and SB3078 are only reported for their putative gene sequences in the genomes and their biochemical properties have not been characterized yet [24].

Multiple sequence alignment showed the five conserved sequence motif regions of glycoside hydrolase family 13 (GH13) [30]. The five conserved regions including the seven highly conserved amino acid residues (His 154 in region I, Arg292 and Asp294 in region II, Glu338 in region III, His402 and Asp 403 in region IV and Ser261 in region V) were also identified in the PmTreS sequence (Fig. 1A). The important roles of amino acid in the conserved region of TreS were studied in previous reports. Mechanistic analysis of trehalose synthase from $M$. smegmatis revealed that Asp230 is a catalytic nucleophilic residue, Glu272 is a general acid/base catalyst, and His341 and Asp342 are conserved carboxylic acids [31]. Furthermore, His120, Asp217, Glu259, Asp329 and His328 significantly affected the catalytic activity of TreS from Thermomonospora curvata DSM 43183 [32]. Moreover, the roles of the five conserved amino acids of TreS from R. opacus were explained. Asp244 and Asp354 might function as nucleophiles that attack the bonded anomeric carbon of maltose, while Glu286 might play a role in proton donation. His 147 and His353 were suggested to act as substrate binding sites [33].

\section{Expression and Purification of PmTreS}

The recombinant plasmid was transformed into the E. coli BL21(DE3) strain for expression. The results showed that induction with $1 \mathrm{mM} \mathrm{IPTG}$ at $18^{\circ} \mathrm{C}$ for $12 \mathrm{~h}$ was the optimal condition for expression of the recombinant protein in soluble form (Fig. S5). Higher temperature led to higher level formation of inclusion bodies, while lower IPTG concentrations decreased the total amount of recombinant protein in the soluble fraction. The apparent molecular weight of the purified PmTreS was approximately $76 \mathrm{kDa}$ (Fig. 1B), which agreed well with the calculated Mw of $76.72 \mathrm{kDa}$. The size of TreS from our strain was comparable to the respective enzyme from $P$. stutzeri CJ38 [19].

\section{Effects of $\mathrm{pH}$ and Temperature on TreS Activity and Stability}

The effects of $\mathrm{pH}$ and temperature on PmTreS activity and stability are shown in Fig. 2. Optimal $\mathrm{pH}$ of the PmTreS was 9.0 (Fig. 2A). However, the enzyme maintained high activity at $\mathrm{pH} 7.0-9.0$, with more than $80 \%$ remaining activity after pre-incubation for $12 \mathrm{~h}$ and $60 \%$ after $24 \mathrm{~h}$ (Fig. 2B). The $\mathrm{pH}$ stability of PmTreS was more stable under alkaline condition compared to other TreS enzymes reported in Table 1. Operation of reactions under 
A

\begin{tabular}{|c|c|c|c|c|c|}
\hline Sources & Region I & Region II & Region III & Region VI & Region V \\
\hline CgTreS & 151 DLVMNHT & 249 GFRLDA & 294 AEANQ & 359 FLRNHD & 221 QPDLN \\
\hline RoTreS & 142 DLVMNHT & 240GFRLDA & 85AEANQ & 350 FLRNHD & 212 QPDLN \\
\hline PpTreS1100aa & 109 ELVINHT & 208 GLRLDA & 53AEANQ & 398 FLRNHD & 180 QPDLN \\
\hline AaTreS & 124 DLPLNHT & 222GFRADA & 67 AEANQ & 331 FLRNHD & 194 QPDLN \\
\hline AcTreS & 124 DLPLNHT & 2 GFRADA & 67 AEANQ & HD & DLN \\
\hline DrTreS & 101 DLVTNHT & 205GFRVDA & 250 AEANQ & 314 FLRNHD & 177 QPDLN \\
\hline EhTreS & 97 ELLIQHT & 193 GFRLDA & 236 GEVDV & 298WLRNHD & 165 EPDLN \\
\hline PsTreS & 149 DIVPAHT & 290 VLRLDA & 337 QELNL & 398ALQNHD & 259 QPSLN \\
\hline PpTreS680aa & 149 DLIPSHT & 290 GLRLDA & 337 QELNL & 398ALQNHD & 259 QPSLN \\
\hline PmTreS & 149 DLIPSHT & 290 GLRLDA & 337 QELNL & 398ALQNHD & 259 QPSLN \\
\hline PmTreS'SB3078 & 149 DLIPSHT & 290 GLRLDA & 337QELNL & 398ALQNHD & 259 QPSLN \\
\hline PmTreS & 149 DLIPSHT & 290 GLRLDA & 337QELNL & 398ALQNHD & 259 QPSLN \\
\hline
\end{tabular}

B

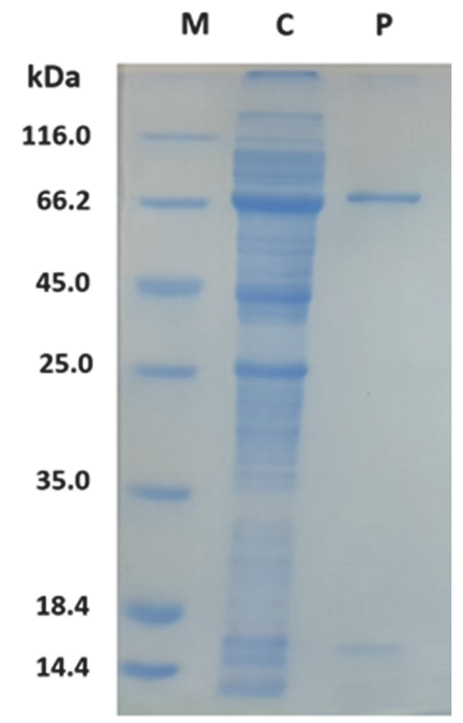

Fig. 1. Comparison of amino acid sequence alignment at the conserved regions of TreS from mesophilic microorganisms (A) and SDS-PAGE analysis of PmTreS purification. (B) Lane C; crude extracts, Lane P; purified PmTreS from Ni Sepharose affinity chromatography column and Lane M; markers. PmTreS: $P$. monteilii TBRC 1196 (this study), PmTreS ${ }_{\mathrm{SB} 3101}$ : P. monteilii [GenBank: AHC88446.1], PmTreS $\mathrm{SB}_{\mathrm{SB} 078}$ : P. monteilii [GenBank: AHC83070.1], PpTreS680aa: P. putida (680aa) [GenBank: QNG09137.1], PsTreS: P. stutzeri [GenBank: AAF26837], PpTreS: P. putida (1106aa) [GenBank: TFF50727.1], AcTreS: A. chlorophenolicus [GenBank: AKA87409.1], AaTreS: A. aurescens [GenBank: ACL80570.1], DrTreS: D. radiodurans [GenBank: AEJ36289], RoTreS. R. opacus [GenBank: AGF84773.1], EhTreS: E. hormaechei [GenBank: ACI16355.1], and CgTreS: C. glutamicum [GenBank: CAF20645].

alkaline condition is considered advantageous as this is unfavorable for the growth of many microorganisms. Most bacteria prefer a $\mathrm{pH}$ range of approximately 5-8 whereas most fungi grow optimally at a $\mathrm{pH}$ range of approximately 5.0-6.0 [34]. This suggests the effects of alkalinity on inhibition of microbial contamination.

The optimal temperature for this enzyme was $40^{\circ} \mathrm{C}$ (Fig. 2C), which was higher than that for many previously reported TreS enzymes isolated from mesophilic microorganisms as shown in Table 1, for example Pseudomonas sp. P8005, P. stutzeri CJ38, P. putida NBRI0987, C. glutamicum ATCC13032, D. radiodurans DSMZ 20539, $R$. opacus ACCC 41021, A. aurescens CGMCC 1.1892 and A. chlorophenolicus SK33.001, which showed optimal temperatures ranging from 25 to $37^{\circ} \mathrm{C}[17-19,23,33,35-37]$ but lower than those for TreS enzymes from thermophilic microorganisms such as Thermus sp., Thermobaculum sp., Picrophilus sp. and Meiothermus sp., which have an optimal temperature range between $45-65^{\circ} \mathrm{C}[16,22,38-40]$. All of the reported TreS enzymes from mesophilic and thermophilic sources showed their optimal $\mathrm{pH}$ in the neutral or less alkaline range compared to the PmTreS, except for the enzyme from Thermus sp., had an optimal pH at 9, similar to our enzyme. For the stability test, PmTreS showed more than $90 \%$ remaining activity for $6 \mathrm{~h}$ and almost $70 \%$ for $24 \mathrm{~h}$ at 20 to $40^{\circ} \mathrm{C}$, while its activity markedly dropped to lower than $30 \%$ at $50^{\circ} \mathrm{C}$, as shown in Fig. 2D. Its thermostability at up to $40^{\circ} \mathrm{C}$ was higher than that of many previously reported TreS enzymes from mesophilic microbial sources that showed only $80 \%$ activity remaining after incubation at $40^{\circ} \mathrm{C}$ for $30 \mathrm{~min}[13,18,35]$. High activity and stability at the optimal mesophilic temperature allow cost saving in terms of required heating energy [13] and are considered desirable characteristics for its use in cell surface-displayed forms $[9,41,42]$. 
A

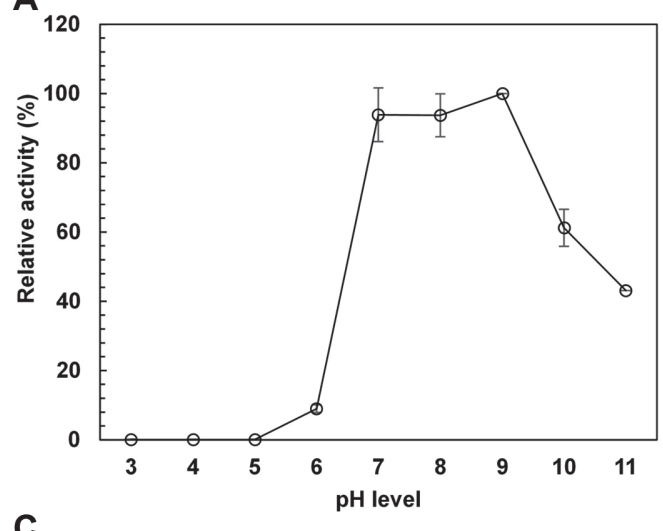

C

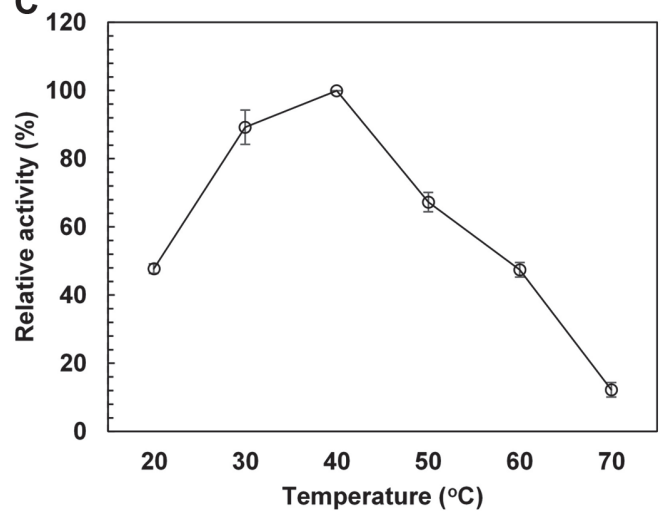

B

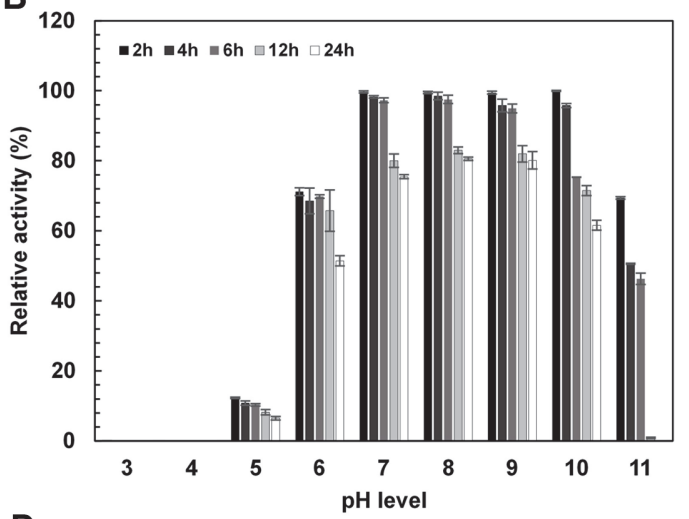

D

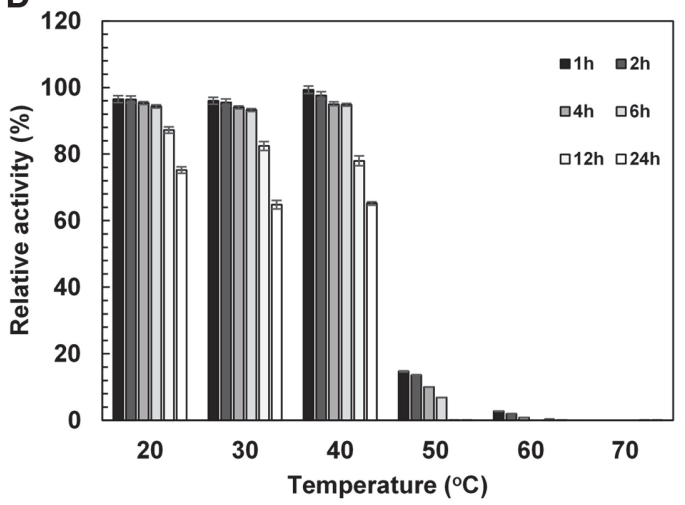

Fig. 2. Effects of pH and temperature on PmTreS activity and stability. (A) Relative activity at different pHs, (B) stability at different $\mathrm{pHs},(\mathbf{C})$ relative activity at different temperatures, (D) thermostability. For $\mathrm{pH}$ stability determination, the enzyme was pre-incubated at $30^{\circ} \mathrm{C}$ at different $\mathrm{pHs}$ before measuring activity at $40^{\circ} \mathrm{C}, \mathrm{pH} 7.0$. For thermostability test, the enzyme was pre-incubated at different temperatures at $\mathrm{pH} 7.0$ before determining activity at $40^{\circ} \mathrm{C}, \mathrm{pH} 7.0$. One hundred percent of enzyme activity was $6.4 \mathrm{U} / \mathrm{mg}$ protein.

Effects of Metal Ions and Inhibitors on Activity

The activity of PmTreS significantly increased ( $p$-value $\leq 0.05)$ with addition of metal ions $\left(\mathrm{Mg}^{2+}, \mathrm{Ca}^{2+}\right.$, and $\mathrm{Mn}^{2+}$ ) whereas the presence of $\mathrm{Zn}^{2+}, \mathrm{Cu}^{2+}$ and $\mathrm{Ni}^{2+}$ strongly inhibited enzyme activity (Table 2). It is well known that glycosidase activity is affected by the presence of metal ions [43]. Some cations like $\mathrm{Ca}^{2+}$ are required by other enzymes in the GH13 hydrolase family, which stabilizes the linkage of the $(\alpha / \beta) 8$-barrel $[44,45]$. Inhibition of some $\mathrm{GH} 13$ hydrolases by $\mathrm{Cu}^{2+}$ could be due to competition between the exogenous cation and the proteinassociated cations, resulting in decreased enzyme activity [46, 47]. The $\mathrm{Cu}^{2+}$ cation also showed a strong inhibitory effect on TreS from previously reported bacterial species such as P. stutzeri, P. torridus, A. aurescens, E. hormaechei, C. glutamicum, $M$. ruber and D. radiodurans $[16-19,22,37,48]$. However, the addition of metal ions such as $\mathrm{Fe}^{2+}$ and $\mathrm{Ba}^{2+}$ did not significantly affect activity ( $p$-value $>0.05$ ).

\section{Effects of Substrate Concentration and Enzyme Loading on Trehalose and Glucose Formation}

The effect of substrate concentration on yield and specificity of trehalose by PmTreS was examined at $\mathrm{pH} 9.0$ and $40^{\circ} \mathrm{C}$ using TreS loading of $2 \mathrm{mg} / \mathrm{g}$ substrate. Yields of trehalose at maltose concentrations of 10, 50, 100, 150, 200 , and $250 \mathrm{~g} / \mathrm{l}$ were between 44.6 and $66.1 \%$. Glucose yields were observed at $1.8-5.6 \%$, except at $10 \%$ maltose concentration which showed a high glucose yield of $19.6 \%$ (Fig. 3A). Glucose formation decreased with increasing initial maltose concentration, suggesting inhibition of hydrolytic activity of this enzyme at high maltose concentration. Generally, TreS from thermophilic or mesophilic bacteria was used at reaction temperatures higher than $35^{\circ} \mathrm{C}$. High amounts of glucose as a byproduct in the range of 7.3-19.2\% were reported [16-18, 22, 32, $35,37]$ due to increased flexibility of the protein structure at higher temperatures, making the catalytic pocket more accessible to water molecules that attacked the split glucose before the formation of $a, a-1,1$-glycosidic bonds $[13,49]$. Our PmTreS showed an optimal reaction temperature of $40^{\circ} \mathrm{C}$ with lower glucose as a byproduct than previously reported, indicating its desirable properties and potential for future applications.

The effects of enzyme loading on trehalose yield and specificity were studied in reaction containing $100 \mathrm{~g} / \mathrm{l}$ maltose using TreS loading of $1-4 \mathrm{mg} / \mathrm{g}$ substrate. The highest trehalose yield of $68.1 \%$ was obtained using an enzyme loading of $2 \mathrm{mg} / \mathrm{g}$ (Fig. 3B). With its high specific activity ( $90.2 \mathrm{U} / \mathrm{mg}$ protein) compared to TreS enzymes from other mesophilic bacteria (Table 1), this could allow the use of relatively low enzyme loading of PmTreS in the trehalose synthesis reaction. 
Table 1. Characteristics of recombinant trehalose synthases from mesophilic microorganisms.

\begin{tabular}{|c|c|c|c|c|c|c|c|c|c|}
\hline \multirow[b]{2}{*}{ Microorganism } & \multirow[b]{2}{*}{$\begin{array}{l}\text { Opt. } \\
\text { pH }\end{array}$} & \multirow[b]{2}{*}{$\begin{array}{l}\text { Opt. } \\
\text { Temp } \\
\left({ }^{\circ} \mathrm{C}\right)\end{array}$} & \multirow[b]{2}{*}{$\begin{array}{c}\mathrm{pH} \\
\text { stability }\end{array}$} & \multirow[b]{2}{*}{ Thermostability } & \multicolumn{5}{|c|}{ Enzymatic conversion } \\
\hline & & & & & $\begin{array}{c}\text { Spec. } \\
\text { activity } \\
(\mathrm{U} / \mathrm{mg})\end{array}$ & $\begin{array}{c}\text { Trehalose } \\
\text { yield }\end{array}$ & $\begin{array}{c}\text { Glucose } \\
\text { yield } \\
\text { (byproduct) }\end{array}$ & $\begin{array}{l}\text { Condition } \\
\text { Temp. | } \\
\text { time }\end{array}$ & References \\
\hline $\begin{array}{l}\text { Pseudomonas } \\
\text { monteilii TBRC } \\
1196\end{array}$ & 9 & 40 & $\begin{array}{l}>90 \%(\mathrm{pH} 7- \\
9,12 \mathrm{~h}) \\
\sim 61 \%(\mathrm{pH} \\
10,24 \mathrm{~h})\end{array}$ & $\begin{array}{l}>90 \%\left(20-40^{\circ} \mathrm{C},\right. \\
6 \mathrm{~h}) \\
\sim 80 \%\left(20-40^{\circ} \mathrm{C},\right. \\
12 \mathrm{~h}) \\
\sim 65 \%\left(20-40^{\circ} \mathrm{C},\right. \\
24 \mathrm{~h}) \\
14 \%\left(50^{\circ} \mathrm{C}, 2 \mathrm{~h}\right)\end{array}$ & 90.6 & $68 \%$ & $4 \%$ & $40^{\circ} \mathrm{C} \mid 15 \mathrm{~h}$ & This study \\
\hline $\begin{array}{l}\text { Pseudomonas sp. } \\
\text { [GenBank: } \\
\text { AFK94626] }\end{array}$ & 7.2 & 37 & $\begin{array}{l}>95 \%(\mathrm{pH} 7 \\
1 \mathrm{~h}) \\
\sim 75 \%(\mathrm{pH} 8 \\
1 \mathrm{~h})\end{array}$ & $\begin{array}{l}>80 \%(10- \\
\left.40^{\circ} \mathrm{C}, 30 \mathrm{~min}\right) \\
10 \%\left(50^{\circ} \mathrm{C},\right. \\
30 \mathrm{~min})\end{array}$ & NR & $70 \%$ & $8 \%$ & $37^{\circ} \mathrm{C} \mid 12 \mathrm{~h}$ & {$[35]$} \\
\hline $\begin{array}{l}\text { Pseudomonas } \\
\text { stutzeri } \\
\text { [GenBank: } \\
\text { AAF26837] }\end{array}$ & 8.5 & 35 & pH 5.5-9.0 & $40 \%\left(55^{\circ} \mathrm{C}, 1 \mathrm{~h}\right)$ & 79.2 & $\begin{array}{l}75 \% \\
72 \%\end{array}$ & $\begin{array}{l}0 \% \\
0 \%\end{array}$ & $\begin{array}{l}15^{\circ} \mathrm{C} \mid 19 \mathrm{~h} \\
35^{\circ} \mathrm{C} \mid 19 \mathrm{~h}\end{array}$ & [19] \\
\hline $\begin{array}{l}\text { Pseudomonas } \\
\text { putida } \\
\text { [GenBank: } \\
\text { GU396283] }\end{array}$ & 7.5 & 38 & $\begin{array}{l}>95 \%(\mathrm{pH} 7 \\
1 \mathrm{~h}) \\
\sim 75 \%(\mathrm{pH} 8 \\
1 \mathrm{~h})\end{array}$ & $20 \%\left(42^{\circ} \mathrm{C}, 1 \mathrm{~h}\right)$ & NR & $72 \%$ & Not reported & $38^{\circ} \mathrm{C} \mid \mathrm{NR}$ & {$[36]$} \\
\hline $\begin{array}{l}\text { Corynebacterium } \\
\text { glutamicum } \\
\text { [GenBank: } \\
\text { CAF20645] }\end{array}$ & 7 & 35 & $\begin{array}{l}\sim 100 \%(\mathrm{pH} \\
7.5,1 \mathrm{~h}) \\
\sim 70 \%(\mathrm{pH} 8 \\
1 \mathrm{~h})\end{array}$ & $\begin{array}{l}80 \%\left(40^{\circ} \mathrm{C}\right. \\
30 \mathrm{~min})\end{array}$ & NR & $\begin{array}{l}67 \% \\
69 \%\end{array}$ & $\begin{array}{l}\sim 14 \% \\
\sim 20 \%\end{array}$ & $\begin{array}{l}25^{\circ} \mathrm{C} \mid 9 \mathrm{~h} \\
30^{\circ} \mathrm{C} \mid 9 \mathrm{~h}\end{array}$ & {$[18]$} \\
\hline $\begin{array}{l}\text { Deinococcus } \\
\text { radiodurans } \\
\text { [GenBank: } \\
\text { AEJ36289] }\end{array}$ & 7.6 & 30 & $\begin{array}{l}\sim 100 \%(\mathrm{pH} \\
7.5,1 \mathrm{~h}) \\
\sim 85 \%(\mathrm{pH} 8 \\
1 \mathrm{~h})\end{array}$ & $\begin{array}{l}50 \%\left(40^{\circ} \mathrm{C},\right. \\
28.5 \mathrm{~h}) \\
\left(50^{\circ} \mathrm{C}, 9.5 \mathrm{~h}\right)\end{array}$ & 11.4 & $58 \%$ & $7.1 \%$ & $30^{\circ} \mathrm{C} \mid 24 \mathrm{~h}$ & {$[17]$} \\
\hline $\begin{array}{l}\text { Rhodococcus } \\
\text { opacus } \\
\text { [GenBank: } \\
\text { AGF84773] }\end{array}$ & 7 & 25 & $\begin{array}{l}\sim 100 \%(\mathrm{pH} \\
6.5-8.5,1 \mathrm{~h}) \\
\sim 80 \%(\mathrm{pH} \\
10,1 \mathrm{~h})\end{array}$ & $\begin{array}{l}\sim 100 \%(15- \\
\left.45^{\circ} \mathrm{C}, 1 \mathrm{~h}\right) \\
0 \%\left(60^{\circ} \mathrm{C}, 3 \mathrm{~h}\right)\end{array}$ & NR & $67 \%$ & $12 \%$ & $25^{\circ} \mathrm{C} \mid \mathrm{NR}$ & {$[33]$} \\
\hline $\begin{array}{l}\text { Arthrobacter } \\
\text { aurescens } \\
\text { [GenBank: } \\
\text { ACL80570.1] }\end{array}$ & 6.5 & 35 & $\begin{array}{l}\sim 100 \%(\mathrm{pH} \\
5.5-7.5 \\
20 \mathrm{~min}) \\
\sim 70 \%(\mathrm{pH} 8 \\
20 \mathrm{~min})\end{array}$ & $\begin{array}{l}\sim 100 \%(20- \\
\left.35^{\circ} \mathrm{C}, 20 \mathrm{~min}\right) \\
10 \%\left(50^{\circ} \mathrm{C}\right. \\
20 \mathrm{~min})\end{array}$ & NR & $59 \%$ & $13 \%$ & $30^{\circ} \mathrm{C} \mid 8 \mathrm{~h}$ & {$[37]$} \\
\hline $\begin{array}{l}\text { Arthrobacter } \\
\text { chlorophenolicus } \\
\text { [GenBank: } \\
\text { AKA87409.1] }\end{array}$ & 7.5 & 30 & NR & $40 \%\left(50^{\circ} \mathrm{C}, 6 \mathrm{~h}\right)$ & 4.4 & $59 \%$ & $17 \%$ & $30^{\circ} \mathrm{Cl} 12 \mathrm{~h}$ & {$[23]$} \\
\hline
\end{tabular}

Table 2. Effects of metal ions on PmTreS activity.

\begin{tabular}{cc}
\hline Metal ions $(1 \mathrm{mM})$ & Relative activity $(\%)$ \\
\hline $\mathrm{Zn}^{2+}$ & $17.68 \pm 0.00^{\mathrm{b}}$ \\
$\mathrm{Mg}^{2+}$ & $108.14 \pm 1.64^{\mathrm{f}}$ \\
$\mathrm{Ca}^{2+}$ & $105.16 \pm 2.58^{\text {ef }}$ \\
$\mathrm{Mn}^{2+}$ & $106.85 \pm 3.48^{\mathrm{f}}$ \\
$\mathrm{Fe}^{2+}$ & $100.88 \pm 1.37^{\mathrm{de}}$ \\
$\mathrm{Cu}^{2+}$ & $1.84 \pm 0.68^{\mathrm{a}}$ \\
$\mathrm{Ba}^{2+}$ & $96.51 \pm 1.64^{\mathrm{d}}$ \\
$\mathrm{Ni}^{2+}$ & $27.42 \pm 1.99^{\mathrm{c}}$ \\
$\mathrm{Control}^{\mathrm{c}}$ & $100.00 \pm 1.64^{\mathrm{d}}$
\end{tabular}

Different letters within the same column are statistically different at $p \leq 0.05$.

\section{Optimization and Up-Scaling of Trehalose Production Reaction}

We optimized the reactions in trehalose production using PmTreS by studying trehalose yield and specificity at various $\mathrm{pH}(7.0,8.0$, and 9.0$)$ and temperature $\left(30\right.$ and $\left.40^{\circ} \mathrm{C}\right)$ in $50 \mathrm{ml}$ reaction shaking flask experiments. The 

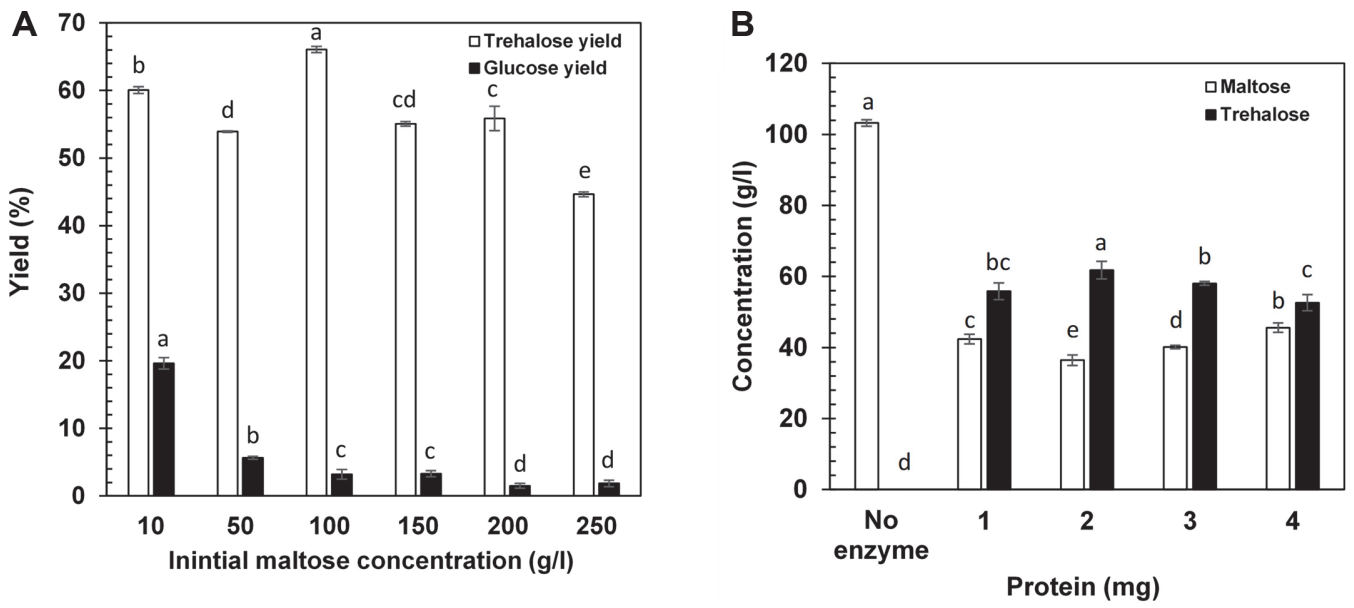

Fig. 3. Effects of substrate concentration (A) and protein concentration (B) on trehalose production by PmTreS. The reactions were carried out in $50 \mathrm{mM}$ glycine- $\mathrm{NaOH}$ buffer $\left(\mathrm{pH} \mathrm{9.0)}\right.$ at $40^{\circ} \mathrm{C}$ for $24 \mathrm{~h}$.

results revealed that the obtained trehalose yield was $64.0-65.7 \%$ at $24 \mathrm{~h}$. Glucose formation (byproduct) ranged from $4.2-5.6 \%$ at $24 \mathrm{~h}$, similar to that obtained in the small-scale experiments (Fig. S6). These findings suggested that high trehalose and low glucose formation could be obtained from PmTreS under these $\mathrm{pH}$ and temperature ranges.

The trehalose production reaction was then studied in an up-scaled experiment in a 2-L bioreactor using 100 and $200 \mathrm{~g} / \mathrm{l}$ maltose at $\mathrm{pH}$ 9, with PmTreS loading of $2 \mathrm{mg} / \mathrm{g}$ substrate. At $100 \mathrm{~g} / \mathrm{l}$ maltose used as the substrate, the highest production of trehalose by PmTreS was $68.1 \mathrm{~g} / \mathrm{l}$ at $15 \mathrm{~h}$. (Fig. $4 \mathrm{~A}$ ). At $200 \mathrm{~g} / \mathrm{l}$, the trehalose concentration was $118.2 \mathrm{~g} / \mathrm{l}$ at $15 \mathrm{~h}$ (Fig. $4 \mathrm{~B})$. A low concentration of glucose as a byproduct ( $\sim 4 \mathrm{~g} / \mathrm{l})$ was obtained under the experimental conditions.

According to previous reports (Table 1), our trehalose yield was higher than that obtained using recombinant TreS from D. radiodurans (GenBank: AEJ36289), A. aurescens (GenBank: ACL80570.1) and A. chlorophenolicus (GenBank: AKA87409.1) [17, 23, 37] but slightly lower than TreS from Pseudomonas sp. (GenBank: AFK94626) and P. stutzeri (GenBank: AAF26837) [19,35]. Compared to most reported mesophilic TreS enzymes, PmTreS showed desirable properties on yield and product specificity with lower byproduct yield than many previously reported enzymes under the experimental conditions, except for TreS from P. stutzeri (GenBank: AAF26837) [19]. However, PmTreS showed higher specific activity than the enzyme from P. stutzeri, potentially leading to lower enzyme cost and shorter reaction time and indicating the potential of the newly reported PmTreS for future applications.

Compared to the reported TreS from thermophilic microorganisms, the PmTreS-catalyzed reaction in our study achieved a higher trehalose yield and lower by-product formation in a shorter reaction time. The performance of TreS enzymes from D. radiodurans [17], M. ruber [22], and P. torridus [16] was demonstrated in trehalose production at $30-45^{\circ} \mathrm{C}$ and led to a trehalose yield of $56.0-61.0 \%$ with relatively higher glucose formation (7.8-9.2\%) using a longer reaction time (24-72 h). The yield obtained in our study was only slightly lower than that from Thermus antranikianii [4] and Thermobaculum terrenum [40], which achieved more than $70 \%$ trehalose

A

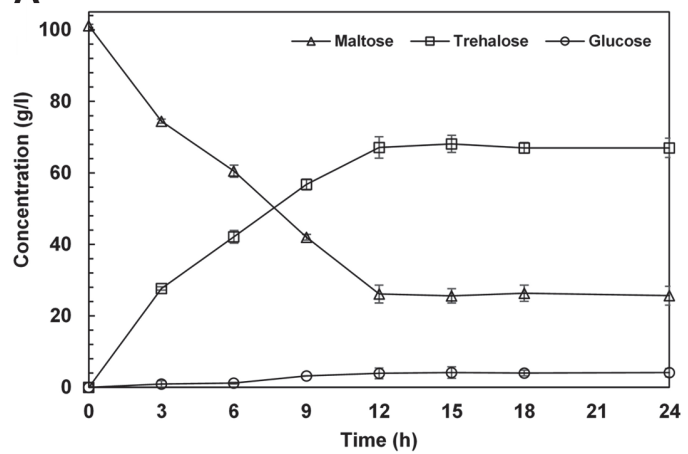

B

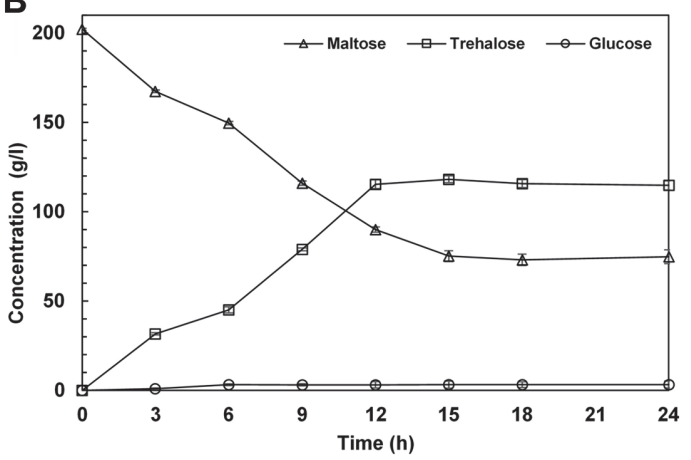

Fig. 4. Up-scaled production of trehalose from 100 (A) and 200 (B) g/l maltose by PmTreS. The reactions were carried out in $50 \mathrm{mM}$ glycine- $\mathrm{NaOH}$ buffer $\left(\mathrm{pH} 9.0\right.$ ) at $40^{\circ} \mathrm{C}$ for $24 \mathrm{~h}$ in a 2-L bioreactor (working volume, $1 \mathrm{~L}$ ). 
yield; however, their specificity as reflected by the formation of glucose byproduct was not reported for these enzymes. The alkalophilicity of PmTreS also potentially inhibits the growth of contaminated microorganisms in the production process [34]. This allows development of an energy-saving trehalose production process operated under mild condition.

In conclusion, the developed method for screening of TreS-producing strains was successfully demonstrated with advantages in terms of time, throughput, and scale. A new TreS enzyme from $P$. montelii showed desirable properties for trehalose production under mesophilic and alkaliphilic conditions, with lower byproduct formation compared to most previously reported enzymes. The mesophilic nature of the enzyme is desirable for its further application on cell surface display forms, either in bacteria or yeasts, in future development. Our demonstration of the enzyme-catalyzed trehalose production process in a bioreactor warranted the further study of this enzyme and showed it potential for future biotechnological application.

\section{Acknowledgments}

This project was supported by a research grant from the National Science and Technology Development Agency, Thailand (Grant No. P-18-52705).

\section{Conflict of Interest}

The authors have no financial conflicts of interest to declare.

\section{References}

1. Ohtake S, Wang, YJ. 2011. Trehalose: current use and future applications. J. Pharm. Sci. 100: 2020-2053.

2. Burek M, WAŚKIEWICZ S, Wandzik I. 2015. Trehalose-properties, biosynthesis and applications. Methods. 3: 9-10.

3. Higashiyama T. 2002. Novel functions and applications of trehalose. Pure Appl. 74: 1263-1269.

4. Lin YF, Su PC, Chen PT. 2020. Production and characterization of a recombinant thermophilic trehalose synthase from Thermus antranikianii. J. Biosci. Bioeng. 129: 418-422.

5. Lemieux RU, Bauer HF. 1954. A chemical synthesis of D-trehalose. Can. J. Chem. 32: 340-344.

6. Elbein AD, Pan YT, Pastuszak I, Carroll D. 2003. New insights on trehalose: a multifunctional molecule. Glycobiology 13: 17R-27R.

7. Mahmud SA, Hirasawa T, Shimizu H. 2010. Differential importance of trehalose accumulation in Saccharomyces cerevisiae in response to various environmental stresses. J. Biosci. Bioeng. 109: 262-266.

8. Wiemken A. 1990 Trehalose in yeast, stress protectant rather than reserve carbohydrate. Antonie Van Leeuwenhoek. 58: $209-217$.

9. Li N, Wang H, Li L, Cheng H, Liu D, Cheng H, et al. 2016. Integrated approach to producing high-purity trehalose from maltose by the yeast Yarrowia lipolytica displaying trehalose synthase (TreS) on the cell surface. J. Agric. Food Chem. 64: 6179-6187.

10. Kobayashi K, Komeda T, Miura Y, Kettoku M, Kato M. 1997. Production of trehalose from starch by novel trehalose-producing enzymes from Sulfolobus solfataricus KM1. J. Ferment. Bioeng. 83: 296-298.

11. Mukai K, Tabuchi A, Nakada T, Shibuya T, Chaen H, Fukuda S, et al. 1997. Production of trehalose from starch by thermostable enzymes from Sulfolobus acidocaldarius. Starch-Stärke. 49: 26-30.

12. Teramoto N, Sachinvala ND, Shibata M. 2008. Trehalose and trehalose-based polymers for environmentally benign, biocompatible and bioactive materials. Molecules 13: 1773-1816.

13. Cai X, Seitl I, Mu W, Zhang T, Stressler T, Fischer L, et al. 2018. Biotechnical production of trehalose through the trehalose synthase pathway: current status and future prospects. Appl. Microbiol. Biotechnol. 102: 2965-2976.

14. Tsusaki K, Nishimoto T, Nakada T, Kubota M, Chaen H, Fukuda S, et al. 1997. Cloning and sequencing of trehalose synthase gene from Thermus aquaticus ATCC 33923. Biochim. Biophys. Acta 1334: 28-32.

15. Pan YT, Edavana VK, Jourdian WJ, Edmondson R, Caroll JD, Pastuszak I, et al. 2004. Trehalose synthase of Mycobacterium smegmatis. Eur. J. Biochem. 271: 4259-4269.

16. Chen YS, Lee GC, Shaw JF. 2006. Gene cloning, expression, and biochemical characterization of a recombinant trehalose synthase from Picrophilus torridus in Escherichia coli. J. Agric. Food Chem. 54: 7098-7104.

17. Filipkowski P, Pietrow O, Panek A, Synowiecki J. 2012. Properties of recombinant trehalose synthase from Deinococcus radiodurans expressed in Escherichia coli. Acta Biochim. Pol. 59: 425-431.

18. Kim TK, Jang JH, Cho HY, Lee HS, Kim YW. 2010. Gene cloning and characterization of a trehalose synthase from Corynebacterium glutamicum ATCC13032. Food Sci. Biotechnol. 19: 565-569.

19. Lee JH, Lee KH, Kim CG, Lee SY, Kim GJ, Park YH, et al. 2005. Cloning and expression of a trehalose synthase from Pseudomonas stutzeri CJ38 in Escherichia coli for the production of trehalose. Appl. Microbiol. Biotechnol. 68: 213-219.

20. Cho YJ, Park OJ, Shin HJ. 2006. Immobilization of thermostable trehalose synthase for the production of trehalose. Enzyme Microb. Technol. 39: 108-113.

21. Nguyen THT, Nguyen TT, Le TH, Nguyen TAT, Nguyen MD, Le, DM, Do TT. 2018. Screening bacterial strains for production of maltooligosyl trehalose trehalohydrolase and maltooligosyl trehalose synthase. J. Viet. Env. 9: 55-60.

22. Zhu Y, Wei D, Zhang J, Wang Y, Xu H, Xing L, et al. 2010. Overexpression and characterization of a thermostable trehalose synthase from Meiothermus ruber. Extremophiles 14: 1-8.

23. Cai X, Seitl I, Mu W, Zhang T, Stressler T, Fischer L, et al. 2019. Characterization of a recombinant trehalose synthase from Arthrobacter chlorophenolicus and its unique kinetics indicating a substrate cooperativity. Appl. Biochem. Biotechnol. 187: 12551271.

24. Dueholm MS, Albertsen M, D'Imperio S, Tale VP, Lewis D, Nielsen, PH., et al. 2014. Complete genome sequences of Pseudomonas monteilii SB3078 and SB3101, two benzene-, toluene-, and ethylbenzene-degrading bacteria used for bioaugmentation. Genome Announ. 2: e00514-e00524.

25. Kuschel B, Seitl I, Glück C, Mu W, Jiang B, Stressler T, et al. 2017. Hidden reaction: mesophilic cellobiose 2-epimerases produce lactulose. J. Agric. Food Chem. 65: 2530-2539.

26. Maruta K, Nakada T, Kubota M, Chaen H, Sugimoto T, Kurimoto M, et al. 1995. Formation of trehalose from maltooligosaccharides by a novel enzymatic system. Biosci. Biotechnol. Biochem. 59: 1829-1834.

27. Zhu Y, Zhang J, Wei D, Wang Y, Chen X, Xing L, et al. 2008. Isolation and identification of a thermophilic strain producing trehalose synthase from geothermal water in China. Biosci. Biotechnol. Biochem. 72: 2019-2024.

28. Dong Y, Ma L, Duan Y. 2016. The effect of high pressure on the intracellular trehalose synthase activity of Thermus aquaticus. World J. Microbiol. 32: 11 .

29. Schiraldi C, Lernia I Di, Rosa M De. 2002. Trehalose production: exploiting novel approaches. Trends Biotechnol. 20: 420-425. 
30. Janeček Š, Svensson B, MacGregor EA. 2014. a-Amylase: an enzyme specificity found in various families of glycoside hydrolases. Cell Mol. Life Sci. 71: 1149-1170.

31. Zhang R, Pan YT, He S, Lam M, Brayer GD, Elbein AD, et al. 2011. Mechanistic analysis of trehalose synthase from Mycobacterium smegmatis. J. Biol. Chem. 286: 35601-35609.

32. Liang J, Huang R, Huang Y, Wang X, Du L, Wei Y. Cloning, expression, properties, and functional amino acid residues of new trehalose synthase from Thermomonospora curvata DSM 43183. J. Mol. Catal. B Enzym. 90: 26-32.

33. Yan J, Qiao Y, Hu J, Ding H. 2013. Cloning, expression and characterization of a trehalose synthase gene from Rhodococcus opacus. Protein J. 32: 223-229.

34. Keenleyside W. 2019. Microbiology: Canadian Edition. Pressbooks, Montreal, Canada.

35. Gao Y, Xi Y, Lu XL, Zheng H, Hu B, Liu XY, et al. 2013. Cloning, expression and functional characterization of a novel trehalose synthase from marine Pseudomonas sp. P8005. World J. Microbiol. Biotechnol. 29: 2195-2206.

36. Vardharajula S. 2013. Isolation and identification of a thermotolerant plant growth promoting Pseudomonas putida producing trehalose synthase. J. Microbiol. Biotechnol. Food Sci. 3: 63-68.

37. Wu XL, Ding HB, Yue M, Qiao Y. 2009. Gene cloning, expression, and characterization of a novel trehalose synthase from Arthrobacter aurescens. Appl. Microbiol. Biotechnol. 83: 477-482.

38. Li Y, Sun X, Feng Y, Yuan Q. 2015. Cloning, expression and activity optimization of trehalose synthase from Thermus thermophilus HB27. Chem. Eng. Sci. 135: 323-329.

39. Wang JH, Tsai MY, Chen JJ, Lee GC, Shaw JF. 2007. Role of the C-terminal domain of Thermus thermophilus trehalose synthase in the thermophilicity, thermostability, and efficient production of trehalose. J. Agric. Food Chem. 55: 3435-3443.

40. Wang J, Ren X, Wang R, Su J, Wang F. 2017. Structural characteristics and function of a new kind of thermostable trehalose synthase from Thermobaculum terrenum. J. Agric. Food Chem. 65: 7726-7735.

41. Yang S, Lv X, Wang X, Wang J, Wang R, Wang T. 2017. Cell-surface displayed expression of trehalose synthase from Pseudomonas putida ATCC 47054 in Pichia pastoris using Pirlp as an anchor protein. Front. Microbiol. 8: 2583

42. Liu H, Yang S, Wang X, Wang T. 2019. Production of trehalose with trehalose synthase expressed and displayed on the surface of Bacillus subtilis spores. Microb. Cell Fact. 18: 1-13.

43. Buisson G, Duee E, Haser R, Payan F. 1987. Three dimensional structure of porcine pancreatic alpha-amylase at 2.9 A resolution. Role of calcium in structure and activity. EMBO J. 6:3909-3916.

44. Linden A, Mayans O, Meyer-Klaucke W, Antranikian G, Wilmanns M. 2003. Differential regulation of a hyperthermophilic aamylase with a novel (Ca, Zn) two-metal center by zinc. J. Biol. Chem. 278: 9875-9884.

45. Chai KP, Othman NFB, Teh A-H, Ho KL, Chan K-G, Shamsir MS, et al. 2016. Crystal structure of Anoxybacillus $\alpha$-amylase provides insights into maltose binding of a new glycosyl hydrolase subclass. Sci. Rep. 6: 23126.

46. Li H, Chi Z, Wang X, Duan X, Ma L, Gao L. 2007. Purification and characterization of extracellular amylase from the marine yeast Aureobasidium pullulans N13d and its raw potato starch digestion. Enzyme Microb. Technol. 40: 1006-1012.

47. Chakraborty S, Raut G, Khopade A, Mahadik K, Kokare C. 2012. Study on calcium ion independent $\alpha$-amylase from haloalkaliphilic marine Streptomyces strain A3. Indian J. Biotech. 11: 427-437.

48. Yue M, Wu XL, Gong WN, Ding HB. 2009. Molecular cloning and expression of a novel trehalose synthase gene from Enterobacter hormaechei. Microb. Cell Fact. 8: 34.

49. Koh S, Kim J, Shin HJ, Lee D, Bae J, Kim D, et al. 2003. Mechanistic study of the intramolecular conversion of maltose to trehalose by Thermus caldophilus GK24 trehalose synthase. Carbohydr. Res. 338: 1339-1343. 